\title{
Trans-Activator Protein BZLF1
}

National Cancer Institute

\section{Source}

National Cancer Institute. Trans-Activator Protein BZLF1. NCI Thesaurus. Code C118473.

Trans-activator protein BZLF1 (245 aa, $27 \mathrm{kDa}$ ) is encoded by the Epstein-Barr virus BZLF1 gene. This protein is involved in the induction of both the expression of early lytic cycle genes and the replication of the viral genome. 